\title{
Differences in Oleic Acid Levels in Matured Milk in the Nutritional Status of Breastfeeding Mothers with Normal and Chronic Energy Deficient
}

\author{
Inka Sumule $^{1}$, Citrakesumasari ${ }^{1}$, Nurpudji Astuti Daud ${ }^{1}$, Abdul Salam $^{1}$, Rahayu Indriasari ${ }^{1}$, \\ Erniwati Ibrahm ${ }^{1}$ \\ *Correspondence: inkasumule2@gmail.com \\ ${ }^{1}$ Graduate School of Public Health, Hasanuddin University, Indonesia
}

\begin{abstract}
This study aims to determine the oleic acid levels of mature breast milk and to analyze differences in oleic acid levels in mature breastfeeding mothers with chronic energy deficiency (KEK) nutritional status and normal nutritional status. This type of research is analytic observation with a cross sectional approach. The population in this study was mature breastfeeding mothers who were in the work area of Sudiang and Sudiang Raya Public Health Centers. The sample in the study was breastfeeding mother's milk aged 2 weeks- 6 months. The sampling technique used was purposive sampling method, a sample size of 38 consisting of 19 breastfeeding mothers and 19 breastfeeding mothers with normal nutritional status. Data were analyzed using the Manwithney test. The results of the study found that oleic acid levels in SEZ breastfeeding mothers were in the range of $0.7-1.7$, with an average of $0.95 \pm$ 0.198 and normal breastfeeding mothers, the oleic acid levels ranged from 0.6 to 1.4 with an average of $0,94 \pm 0.195$. The results of statistical tests found no significant difference $p=$ 0.317 levels of oleic acid in breastfeeding mothers, the nutritional status of KEK compared to normal nutritional status. Oleic acid levels in breast milk for breastfeeding mothers with KEK were $94.7 \%$, category less than the reference and in breastfeeding mothers the normal nutritional status was $100 \%$ lower than the reference level $(1.5 \mathrm{gr} / \mathrm{L})$.
\end{abstract}

Keywords: Matured Breastfeeding, Oleic Acid, Nutritional Status, Exclusive Breastfeeding

Received: October 22, 2020

Received in Revised: November 3, 2020

Accepted: November 13, 2020

\section{Introduction}

World Breastfeeding Trends Initiative 2012, Indonesia is ranked very low in supporting exclusive breastfeeding (WBTi, 2020). In an effort to support and increase exclusive breastfeeding, various global and national agreements have been issued that aim to protect, promote and support exclusive breastfeeding. The 3rd Sustainable Development Goals (SDGs), the 2nd target by 2030, all countries are trying to reduce the neonatal mortality rate (IMR) by at least 12 per 1,000 live births (Hastuti \& Wijayanti, 2017).

According to the Principle of Nutritional Assessment nutritional status is the state of the body which is the final result of the balance between the nutrients that enter the body and its functions. Fat reserves before pregnancy will be sufficient for breastfeeding in infants aged 4 - 6 months. The 2018 Indonesian Health Profile Report shows that nationally the coverage of exclusive breastfeeding in Indonesia is $65.16 \%$. Meanwhile, based on the 2018 Basic Health Research report, it shows that nationally the coverage of exclusive breastfeeding for babies is $37.8 \%$, and for Sulawesi province South is above the national average but has not reached the national target (Ministry of Health, 2018). 
Breastmilk (ASI) is a very effective food for babies. Exclusive breastfeeding is given to babies for the first 6 months without other foods. Breast milk contains balanced nutrition from a qualitative and quantitative perspective, the composition of breast milk is dynamic and varies according to the nutritional status of the mother (Bzikowska, 2018). In studies conducted in India and Guatemala, the low protein content in breast milk is influenced by the nutritional status of mothers who are deficient in breastfeeding mothers. This study is in line with that conducted by Quinn et al. (2012) on the relationship between maternal nutrition and body composition of the nutritional quality of breast milk, showing that food intake factors do not affect the quality of breast milk, but affect the composition of the mother's body which is closely related to the quality of breast milk.

Maternal nutritional status is one of the factors that can affect the quality of breast milk. Mothers who have a good nutritional status have adequate nutritional reserves, so that they can produce breast milk smoothly and have sufficient nutritional content. In previous studies, it was stated that the nutritional status of mothers during breastfeeding had an effect on the success of mothers in breastfeeding, mothers who had low nutritional status had a risk of not succeeding in breastfeeding 2.26-2.56 times greater when compared to mothers with normal nutritional status (Maharani et al., 2016).

The results of other studies also show that mothers with good nutritional status are generally able to breastfeed their babies for at least 6 months. The results of other studies also stated that mothers with poor nutritional status had a 3,638 times greater risk of not being able to provide exclusive breastfeeding compared to mothers with good nutritional status. Other studies have also said that changes in the composition of breast milk are influenced by the weaning process. Furthermore, it is said that the volume of milk can decrease by up to $66 \%$ of the volume of the initial breastfeeding when the baby starts weaning. The protein concentration in milk increased 1.6 times in weaned mothers, while in unweaned mothers the protein concentration in milk was 2.8 times. Some studies also suggest that changes in the composition of breast milk in nursing mothers are influenced by the weaning process. Other factors also affect the composition of breast milk, including parity, food intake, gender and maternal health status (Verd et al., 2018).

Psychological factors affect the amount of breast milk including the capacity of the mother to produce milk, the ability to express milk and the ability of the baby to consume breast milk as well as to stimulate the nipples so that more milk is excreted. The frequency, duration and strength of the baby's suckling can have an impact on the quantity or volume of milk.

The main factors that can affect the composition and quality of breast milk are the stages of lactation (color costume, lactation initiation, transition, maturity) of preterm birth (Chung et al., 2014). Lactation initiation, early birth, skin contact between mother and baby during the first hour after birth (IMD) is one of the factors that can result in an increase in breastfeeding 1-4 months after birth (Lumbiganon et al., 2016). Another factor is the nutritional status of the mother, the total amount of breast milk production and the intake to the baby varies greatly for each breastfeeding time with the amount ranging from $750-850 \mathrm{ml}$ per day.

Other studies also investigated the relationship between maternal body composition and lactose protein and lactose concentrations during the first year of lactation, which gave significant results between the body composition of breastfeeding mothers and the concentration of components of breast milk (Kugananthan et al., 2017; Dritsakou et al., 2017). Research conducted in Kenya explained that the volume of breast milk consumed by infants is significantly affected by the upper arm circumference (LILA) of breastfeeding mothers during pregnancy (Ettyang, 2005). 
Optimal breastfeeding practices include initiation of direct skin-to-skin contact with breastfeeding within 1 hour after birth, exclusive breastfeeding without other foods for 6 months and complementing breastfeeding with appropriate foods after 6 months and up to 24 months of age ( Kramer, 1987). Breastfeeding will improve not only children's health but also children's cognitive skills (Borra et al., 2012). This understanding is the same as research that has been conducted that long duration of breastfeeding can be associated with better cognitive and motor development in children (Bernard et al., 2013).

Breast milk can reduce the risk of being overweight, preventing infections such as rotavirus diarrhea and hand, foot and mouth disease in infants (Didehbani et al., 2016). In addition to infectious diseases, long-term breastfeeding reduces the risk of obesity, diabetes and cardiovascular disease (Leonnerdal, 2016; Muhrifan et al., 2020). Research in Chile in 2018 suggested that breastfeeding emerged as a protective factor. The group that was breastfed from 3 to 6 months had a lower prevalence of obesity and a component of the metabolic syndrome than the 0 to 3 months group. This is in line with the opinion of Yang (2018) and Parenreng et al (2020) that protein is quite important to play a role in infant growth and overweight in both quantity and quality.

The composition of the nutrients in breast milk is alpha-lactolbumin and fatty acids. Fatty acids are divided into omega-3, omega-6 and omega-9. Oleic acid (omega-9) can reduce the risk of coronary heart disease, cardiometabolic, type 2 diabetes and hypertension. Oleic acid also has a protective effect on development for several types of cancer such as breast and colorectal cancer (Arsic., 2017). In infants and children, the content of fatty acids in breast milk is very important, especially oleic acid because oleic acid functions for formation, brain development, transportation, metabolism so that maternal food intake is very important so that breastfeeding in breastfeeding mothers increases (Arsic et al., 2017) .

The content of breast milk protein in the form of alpha-lactalbumin and oleic acid in breast milk, which is a component of human $\alpha$-lactalbumin made lethal to tumor cells (HAMLET). Previous research said Hamlet is a complex relationship consisting of $\alpha$-lactalbumin and oleic acid which has antitumor activity which is directly found in breast milk (Mossberg et al., 2010). Research on oleic acid is still very rare in Indonesia. Oleic acid research has not been reported.

In women of New Zealand ethnicity, the composition of fatty acids, especially oleic acid, is very high (Butts et al., 2018). The amount of breast milk that comes from mothers with poor nutritional status can decrease to the amount of only 100-200 ml per day. The breasts of women who are affected by pregnancy hormones and especially women who have breastfed, will be able to produce a lot of breast milk when the woman is relactating (Roos, 2013). Efforts to improve nutrition in infants aged 0-6 months can be made through improving maternal nutrition. So nursing mothers must have a good nutritional status so that they can produce optimal breast milk and can meet the nutritional needs of the baby (Jafri, 2012). Reduction in maternal nutrition occurs due to inadequate nutritional intake which leads to poor nutritional status, poor quality of breast milk, and a drop in child growth and development (Engidaw, 2019).

The South Sulawesi Provincial Health Office report states that of the 24 districts / cities in South Sulawesi, Makassar City has the highest number of Chronic Energy Deficiency (KEK) cases with 3,373 cases in 2018, and it was also reported that of 10 Puskesmas in Makassar City, Puskesmas Sudiang Raya had the highest number of KEK cases with 218 cases or $(16.1 \%)$. 


\section{Methods}

This type of research used analytic observational with a cross-sectional study approach. The research was carried out in the working area of the Sudiang and Sudiang Raya Puskesmas, Makassar City and at the Hasanuddin University Hospital Laboratory. The population and sample in this study were mature breastfeeding mothers in the work area of Sudiang and Sudiang Raya Puskesmas with a total sample size of 367.The sample in this study was breast milk for mature breastfeeding mothers aged 2 weeks - 6 months using purposive sampling technique with a sample size of 19. samples from breastfeeding mothers with KEK and 19 in normal breastfeeding mothers with a total sample size of 38 samples.

At the beginning of the plan to collect breast milk samples were carried out at the Sudiang Raya puskesmas, but because the conditions at that time were in a pandemic period due to Covid-19 and it was feared that at that time there was a shortage of samples, coordination was carried out with the head of the puskesmas, age doctor, midwife and research. So it was agreed to take two health centers, namely Sudiang and Sudiang Raya puskesmas. Breastmilk sampling is carried out using a health protocol provided that respondents are required to use a mask and face shield and use a hand sanitizer and plastic gloves. As for researchers, using N95 masks, medical masks and face shields also use hand sanitizers and gloves.

Respondent characteristics data covering age, education, occupation, parity obtained by direct interviews, maternal nutritional status (KEK and Normal) were obtained by measuring the mother's upper arm circumference (LILA). Breastfeeding samples were taken at 09.00-11.00 WIB. Breast milk is obtained using the Real Bubbe brand electric breast pump with the serial number RBX-8023S-2 which is then put into a Gea Baby brand breast milk bag and tightly closed then stored in a cool box with the gren lay brand that has been filled with ice bag. The researchers took as many breast milk samples as the mothers produced and then brought them to the laboratory for temporary storage in the Thermo brand of breast milk refrigerator at a temperature of $-20 \mathrm{oC}$. Breastfeeding examination by only taking a sample of 5-10 $\mathrm{ml}$ of milk, to see the oleic acid level of breast milk using the ELISA method. To see the differences in oleic acid levels of mature milk in breastfeeding mothers with KEK nutritional status and normal nutritional status were analyzed using the Mann Withney test and processed using the Windows version of the SPSS 24 program.

\section{Results and Discussion}

\section{Karateristik sampel}

Table 1. Characteristics of breastfeeding mothers respondent

\begin{tabular}{|c|c|c|}
\hline \multirow{2}{*}{$\begin{array}{c}\text { Characteristics of } \\
\text { Respondent }\end{array}$} & \multicolumn{2}{|c|}{$\begin{array}{c}\text { Breastfeeding mothers with chronic and } \\
\text { normal energy deficiency nutritional status }\end{array}$} \\
\cline { 2 - 3 } & $\mathbf{n}$ & $\mathbf{2}$ \\
\hline Mother's Age & & 2.6 \\
\hline$\leq 19$ years & 1 & $\mathbf{7 6 . 3}$ \\
\hline 20-35 years & 29 & 21.1 \\
\hline >35 years & 8 & \\
\hline Mother's Education & & 15.8 \\
\hline Elementary School & 6 & 23.7 \\
\hline Junior School & 9 & $\mathbf{4 7 . 4}$ \\
\hline High School & 18 & \\
\hline
\end{tabular}




\begin{tabular}{|c|c|c|} 
Diploma/Bachelor & 5 & 13.2 \\
\hline Mother's Job & & \\
\hline House Wife & 37 & $\mathbf{9 7 . 4}$ \\
\hline Civil Servant & 1 & 2.6 \\
\hline Mother's Parity & & \\
\hline$\leq 2$ & 7 & 18.4 \\
\hline$>2$ & 31 & $\mathbf{8 1 . 6}$ \\
\hline
\end{tabular}

Source: primary data, 2020

Table 1 shows that the age of breastfeeding mothers is more dominant at the age of 20-35 years with a percentage of $(76.3 \%)$. Maternal education shows that at the High School level has a percentage (47.4\%). In the work of mothers, the dominance of housewives $(97.4 \%)$. In parity, breastfeeding mothers were more in mothers who had more than 2 children $(81.6 \%)$.

Oleic acid levels in breast milk for breastfeeding mothers with chronic and normal nutritional status of the mother

Table. 2 Differences in oleic acid levels in breastfeeding mothers with chronic energy deficiency and normal breastfeeding mothers

\begin{tabular}{|c|c|c|c|c|c|}
\hline \multirow{2}{*}{$\begin{array}{c}\text { Nutritional Status } \\
\text { of Breastfeeding } \\
\text { Mothers }\end{array}$} & \multicolumn{3}{|c|}{ Oleic Acid Breast Milk (gr/L) } & \multirow{2}{*}{ P value* } \\
\cline { 2 - 5 } & $\mathbf{n}$ & Min & Max & Mean \pm SD & \\
\hline $\begin{array}{c}\text { Chronic } \\
\text { Nutritional Status } \\
\text { Normal }\end{array}$ & 19 & 0.7 & 1.7 & $0.95 \pm 0.198$ & 0.317 \\
\hline
\end{tabular}

*Mann whitney test

Source: Primary data processed 2020

Table 3. Relationship between nutritional status of breastfeeding mothers and Oleic Acid Levels of mature breast milk

\begin{tabular}{|c|c|c|c|c|c|c|c|}
\hline \multirow{3}{*}{$\begin{array}{c}\text { Mother's } \\
\text { Nutritional Status }\end{array}$} & \multicolumn{4}{|c|}{$\begin{array}{c}\text { Oleic Acid Breast Milk } \\
(\mathrm{g} / \mathrm{L})\end{array}$} & & & \multirow{3}{*}{$\begin{array}{c}\mathbf{P} \\
\text { value* }\end{array}$} \\
\hline & \multicolumn{2}{|c|}{ Low } & \multicolumn{2}{|c|}{ High } & \multicolumn{2}{|c|}{ Total } & \\
\hline & $\mathrm{n}$ & $\%$ & $\mathrm{n}$ & $\%$ & $\mathrm{~N}$ & $\%$ & \\
\hline $\begin{array}{c}\text { Chronic } \\
\text { Nutritional Status }\end{array}$ & 18 & 94.7 & 1 & 5.3 & 19 & 100 & 0.500 \\
\hline
\end{tabular}

*Fisher's Exact Test

Source: Primary data processed 2020

The results of this study indicate that the oleic acid levels of breast milk in breastfeeding mothers with normal nutritional status are in the range $0.6-1.4 \mathrm{~g} / \mathrm{L}$ with an average oelic acid level of $0.94 \mathrm{~g} / \mathrm{L}$ (standard $1.5 \mathrm{~g} / \mathrm{L}$ ). , while breastfeeding mothers with the nutritional status of KEK were in the range of 0.7-1.7 $\mathrm{g} / \mathrm{L}$ with an average oleic acid level of $0.95 \mathrm{~g} / \mathrm{L}$ (standard $1.5 \mathrm{~g} / \mathrm{L}$ ). There was 1 breastfeeding mother who had oleic acid levels above the standard which occurred in the group of women who breastfed KEK with oleic acid levels of $1.7 \mathrm{~g} / \mathrm{L}$. This study revealed that oleic acid levels in mature breast milk in breastfeeding mothers with normal nutritional status were slightly lower than oleic acid levels in 
breastfeeding mothers with KEK nutritional status, but the difference was not statistically significant ( $p>0.05)$ (table 2). Most of the oleic acid levels of breastfeeding mothers were in mothers with normal nutritional status and low KEK when compared with the $1.5 \mathrm{~g} / \mathrm{L}$ standard, namely (100\% and 94.7\%).

The results of this study indicate that the level of oleic acid in breast milk is almost the same as the average value of $0.95 \mathrm{~g} / \mathrm{L}$ in KEK breastfeeding mothers and normal breastfeeding mothers $0.94 \mathrm{~g} / \mathrm{L}$ but the oleic acid levels are still low, Asian ethnicity (standard $1.5 \mathrm{~g} / \mathrm{L}$ ) even average levels of oleic acid for European and New Zealand ethnicities. Previous research said the composition of Asi in ethnic mothers in Asia, the Maori Islands and the Pacific, New Zealand found that Asian Ethics had high levels of $1.5 \mathrm{~g} / \mathrm{L}$, New Zealand had levels of oleic acid $1.3 \mathrm{~g} / \mathrm{L}$ and the Maori Islands had high levels of low oleic acid $1.2 \mathrm{~g} / \mathrm{L}$ (Butts et al., 2018).

In this study also showed that there was 1 respondent who had oleic acid levels above the standard average $(1.5 \mathrm{~g} / \mathrm{L})$, namely $1.7 \mathrm{~g} / \mathrm{L}$. If we look at the intake of mothers who have high levels of oleic acid compared to the standard, it shows that the mother's energy intake is less, while the mother's fat intake is classified as sufficient with a percentage of $88.5 \%$. The source of fat intake from respondents who have high oleic acid levels comes from beef that is consumed.

The composition of breast varies among breastfeeding mothers. The multidimensional variation in this composition is believed to reflect the baby's needs, geographic area and food supply. Variations in breast composition between mothers were reported in response to cultural differences such as diet and lifestyle and environmental factors (Butts et al., 2018). Other studies also say that the composition of breast milk can be influenced by the weaning process. Other factors that affect the composition of breast milk include parity, food intake, sex and maternal health status (Verd et al., 2018).

The results of other studies also found that high levels of oleic acid were found in breastfeeding mothers with normal nutritional status of $2.3 \mathrm{~g} / \mathrm{L}$ and in breastfeeding mothers with chronic energy deficiency (KEK) levels of oleic acid, namely $1.8 \mathrm{~g} / \mathrm{L}$ and $1.6 \mathrm{~g} / \mathrm{L}$. So this shows that oleic acid levels in mothers are not influenced by nutritional status so that it can explain the importance of breastfeeding as the main source of food even in the nutritional status of mothers with chronic energy deficiency (KEK) (Quinn et al. 2012).

Previous research that has been conducted on Nutrition Recommendations in Pregnancy and lactation says that weight loss in mothers during breastfeeding, BMI, body fat percentage and weight gain in mothers during pregnancy do not affect breast production (Kominiarek \& Rajan, 2016).

One of the factors that influence oleic acid levels is the intake of breastfeeding mothers. From the research report of Citrakesumasari et al (2020), it is said that the nutritional status intake of Chronic Energy Deficient (KEK) and normal breastfeeding mothers is different except for fat intake. Research conducted in Ethiopia explained that the daily intake of food is one of the factors related to nutritional problems, namely Chronic Energy Deficiency (KEK) for breastfeeding mothers and this study also shows that the average intake of nutrients of respondents does not reach the standard of sufficiency rate (Sitotaw). et al., 2017).

Other studies that have also been conducted on the composition of breast fatty acids and fat intake of breastfeeding mothers in South Korea stated that the nutritional status of breastfeeding mothers did not significantly affect the levels of breast fatty acids (Kim et al., 2017). The results of this study indicate that the normal nutritional status of breastfeeding 
mothers' food intake for carbohydrate intake is classified as less with an average presentation of $75.7 \%$, but for sufficient energy intake of $86.1 \%$, protein intake is sufficient with a presentation of $94.7 \%$ and for fat intake of $108 \%$. Meanwhile, the intake of chronic energy deficient (KEK) breastfeeding mothers for food intake sources of less energy with a presentation of $60.3 \%$, less protein intake $78.8 \%, 74.2 \%$ less fat intake, the average carbohydrate intake is less with a presentation of $54.7 \%$. The results of the statistical test of this study are in line with previous research which states that the composition of breast milk is not influenced by the mother's food intake (Vasudevan, 2019). Previous research also revealed that although the determinants of breastfeeding mothers such as intake and good nutritional status can affect the composition of breast milk, most studies have found a weak or non-existent relationship with breast milk composition Quinn et al (2012) and Solimin et al (2014) In this study, oleic acid levels were found in breastfeeding mothers with poor nutritional status. The mother's food intake for energy nutrients and carbohydrates, but for protein and fat intake are in the sufficient category. The results of this study also indicated that adequate fat was related to the quality of oleic acid levels in mothers. The analysis showed that there was no relationship between maternal fat intake and oleic acid levels. Another study also said there was no significant relationship in mothers who consumed high fat intake with breast milk fatty acid levels.

Maternal nutrient intake during lactation has a very important role in improving the quality of breast milk. In the study, high levels of Asiatic oleic acid were found in mothers who consumed less nutritional intake. In terms of energy nutrients, carbohydrates and for fats and proteins, the mother has high levels of oleic acid with sufficient fat intake which can be directly related to the quality of oleic acid levels in mother's breast. The low intake of macro nutrients in some breastfeeding mothers, especially in some developing countries, shows a picture of the condition of the mother's nutritional metabolism. According to marmi, in the nutrition book on reproductive health, breastfeeding mothers with breastfeeding ages 0-6 months need an additional $700 \mathrm{kcal}$ of energy. The results of previous studies said that breastfeeding mothers consume at least two times the extra food per day during breastfeeding (Gautam \& Yadav, 2018).

Previous studies have also suggested that developing countries energy needs during lactation are associated with conditions of household food security, and that breastfeeding women cannot increase their energy intake (Vinoy et al., 2000). For developed countries, the nutritional intake of pregnant and lactating women is often inadequate and very low from the recommended daily intake (RDI) which has been determined by the Nutrition Foundation of Italy. NFI said the addition of the Italian RDI to the energy intake of breastfeeding mothers is $500 \mathrm{kcal} /$ day. However, this is different from the Nutritional Adequacy Ratio (RDA) set in Indonesia, namely the addition of 330kcal. But each report in the age group 19-29 years the need for additional RDA intake is higher, namely $2250 \mathrm{kcal}$ compared to ESFA, which is $1886 \mathrm{kcal}$, as well as the need for fat for the 2019 Indonesian RDA, the addition of fat is $2.2 \mathrm{~g}$ / day for breastfeeding mothers and for the group normal women aged 19-29 years, namely $65 \mathrm{gr} /$ day.

In the SFA report there was an increase of $19 \mathrm{~g} /$ day and in the normal group of women aged $>18$ years it was $0.83 \mathrm{~g} /$ day. When calculated, the total energy demand based on the Indonesian RDA of 2580 is higher than the European ESFA 2386 (Marangoni et al., 2016; EFSA, 2017).

Previous research conducted in New Zealand for various ethnicities in New Zealand, namely Asia, Pacific and European ethnicities native to New Zealand, revealed that the energy and 
protein intake of European New Zealand ethnicities was higher than those of Asian and Pacific ethnicities at higher fat intake. Asian ethnicity compared to other ethnicities. The recommended daily intake (RDI) each shows that Asian ethnicity has a high enough RDI in energy intake $(107 \%)$ and protein $(145 \%)$ when compared to the standard intake category issued in 2003 Indonesian WNPG, namely 80-110\% ( Butts, 2018). Lönnerdal et al (1976) argued that the quality and quantity of breast milk was not affected by malnutrition experienced by the mother.

\section{Conclusion}

From the results of this study, it was concluded that the average oleic acid levels in breastfeeding mothers with low chronic and normal nutritional status were low when compared with the $1.5 \mathrm{~g} / \mathrm{L}$ standard, there was no statistically significant difference $\mathrm{p}>0.05$. It is hoped that further research on the relationship between oleic acid levels in breastfeeding mothers with the intake and nutritional status of the baby.

\section{References}

Arsic, A., Stojanovic, A., \& Mikic, M. (2019). Oleic acid-health benefits and status in plasma phospholipids in the Serbian population. Serbian Journal of Experimental and Clinical Research, 20(2), 3-8.

Bernard, J. Y., De Agostini, M., Forhan, A., Alfaiate, T., Bonet, M., Champion, V., \& EDEN Mother-Child Cohort Study Group. (2013). Breastfeeding duration and cognitive development at 2 and 3 years of age in the EDEN mother-child Cohort. The Journal of pediatrics, 163(1), 36-42.

Borra, C., Iacovou, M., \& Sevilla, A. (2012). The effect of breastfeeding on children's cognitive and noncognitive development. Labour Economics, 19(4), 496-515.

Butts, C. A., Hedderley, D. I., Herath, T. D., Paturi, G., Glyn-Jones, S., Wiens, F., ... \& Gopal, P. (2018). Human milk composition and dietary intakes of breastfeeding women of different ethnicity from the Manawatu-Wanganui region of New Zealand. Nutrients, 10(9), 1231.

Butts, C. A., Hedderley, D. I., Herath, T. D., Paturi, G., Glyn-Jones, S., Wiens, F., ... \& Gopal, P. (2018). Human milk composition and dietary intakes of breastfeeding women of different ethnicity from the Manawatu-Wanganui region of New Zealand. Nutrients, 10(9), 1231.

Bzikowska, A., Czerwonogrodzka-Senczyna, A., Weker, H., \& Wesolowska, A. (2018). Correlation between human milk composition and maternal nutritional status. Roczniki Państwowego Zaktadu Higieny, 69(4).

Chung, J., Lee, J., Spinazzola, R., Rosen, L., \& Milanaik, R. (2014). Parental perception of premature infant growth and feeding behaviors: use of gestation-adjusted age and assessing for developmental readiness during solid food introduction. Clinical pediatrics, 53(13), 1271-1277.

Citrakesumasari., Indriyasi, R., \& Salam, A. (2020). Konsentrasi Alfa-lactaalbumin dan Oleic Acid Pada ASI Matur berdasarkan status gizi Ibu Menyusui. Laporan Penelitian Tingkat Dasar LPPM. Makassar, Universitas Hasanuudin.

Didehbani, N., Allen, T., Kandalaft, M., Krawczyk, D., \& Chapman, S. (2016). Virtual reality social cognition training for children with high functioning autism. Computers in human behavior, 62, 703-711. 
Dritsakou, K., Liosis, G., Valsami, G., Polychronopoulos, E., \& Skouroliakou, M. (2017). The impact of maternal-and neonatal-associated factors on human milk's macronutrients and energy. The Journal of Maternal-Fetal \& Neonatal Medicine, 30(11), 1302-1308.

EFSA. (2017). Dietary Reference Values for nutrients Summary report. European Food Safety Authority. EFSA Supporting Publications, 14(12), e15121E.

Engidaw, M. T., \& Gebremariam, A. D. (2019). Prevalence and associated factors of stunting and thinness among adolescent Somalian refugee girls living in eastern Somali refugee camps, Somali regional state, Southeast Ethiopia. Conflict and health, 13(1), 17.

Ettyang, G. A., van Marken Lichtenbelt, W. D., Esamai, F., Saris, W. H., \& Westerterp, K. R. (2005). Assessment of body composition and breast milk volume in lactating mothers in pastoral communities in Pokot, Kenya, using deuterium oxide. Annals of Nutrition and Metabolism, 49(2), 110-117.

Gautam, U., \& Yadav, D. K. (2018). Dietary Practices of Lactating Women and Nutritional Status of Children in Baglung District, Nepal. Journal of Nepal Paediatric Society, 38(1), 19-24.

Hastuti, P., \& Wijayanti, I. T. (2017). Analisis Deskriptif Faktor yang Mempengaruhi Pengeluaran ASI pada Ibu Nifas di Desa Sumber Kecamatan Sumber Kabupaten Rembang. URECOL, 223-232.

Jafri. Y. (2012). Hubungan asupan zat gizi pada ibu menyusui terhadap kadar zink dan besi ASI serta pertumbuhan linier anak. Thesis, Universitas Juanda.

Kemenkes. (2018). Riset Kesehatan Dasar (Riskesdas). Jakarta. Kementerian Kesehatan. Available from: https://kesmas.kemkes.go.id/assets/upload/dir_519d41d8cd98f00/files/Hasilriskesdas-2018_1274.pdf

Kim, H., Kang, S., Jung, B. M., Yi, H., Jung, J. A., \& Chang, N. (2017). Breast milk fatty acid composition and fatty acid intake of lactating mothers in South Korea. British Journal of Nutrition, 117(4), 556-561.

Kominiarek, M. A., \& Rajan, P. (2016). Nutrition recommendations in pregnancy and lactation. Medical Clinics, 100(6), 1199-1215.

Kramer, M. S. (1987). Determinants of low birth weight: methodological assessment and meta-analysis. Bulletin of the world health organization, 65(5), 663.

Kugananthan, S., Gridneva, Z., Lai, C. T., Hepworth, A. R., Mark, P. J., Kakulas, F., \& Geddes, D. T. (2017). Associations between maternal body composition and appetite hormones and macronutrients in human milk. Nutrients, 9(3), 252.

Lönnerdal, B. (2016). Bioactive proteins in human milk: health, nutrition, and implications for infant formulas. The Journal of pediatrics, 173, S4-S9.

Lönnerdal, B., Forsum, E., Gebre-Medhin, M., \& Hambraeus, L. (1976). Breast milk composition in Ethiopian and Swedish mothers. II. Lactose, nitrogen, and protein contents. The American journal of clinical nutrition, 29(10), 1134-1141. 
Lumbiganon, P., Martis, R., Laopaiboon, M., Festin, M. R., Ho, J. J., \& Hakimi, M. (2016). Antenatal breastfeeding education for increasing breastfeeding duration. Cochrane Database of Systematic Reviews, (12).

Maharani, H., Pangestuti, D. R., \& Pradigdo, S. F. (2016). Faktor-faktor yang Berhubungan dengan Status Gizi Ibu Menyusui di Wilayah Kerja Puskesmas Kedungmundu Kota Semarang. Jurnal Kesehatan Masyarakat (e-Journal), 4(3), 187-196.

Marangoni, F., Cetin, I., Verduci, E., Canzone, G., Giovannini, M., Scollo, P\& Poli, A. (2016). Maternal diet and nutrient requirements in pregnancy and breastfeeding. An Italian consensus document. Nutrients, 8(10), 629.

Mossberg, A. K., Hun Mok, K., Morozova-Roche, L. A., \& Svanborg, C. (2010). Structure and function of human $\alpha$-lactalbumin made lethal to tumor cells (HAMLET)-type complexes. The FEBS journal, 277(22), 4614-4625.

Muhrifan, A., Citrakesumasari, C., Djide, N., Sirajuddin, S., Djafar, N., \& Naim, F. (2020). Differences of Oleic Acid Levels in Breast Milk of Lactating Mothers with Chronic Energy Deficiency (CED) and Normal Status. Journal of Scientific Research in Medical and Biological Sciences, 1(2), 161-170.

Parenreng, K. M., Hadju, V., Bahar, B., Jafar, N., Hidayanty, H., \& Saleh, L. M. (2020). Determinants of Stunting Events in Children Aged 6-23 Months in Locus and NonLocus Areas in East Luwu Regency. Journal La Medihealtico, 1(6), 7-16.

Quinn, E. A., Largado, F. E., Power, M., \& Kuzawa, C. W. (2012). Predictors of breast milk macronutrient composition in Filipino mothers. American journal of human biology, 24(4), 533-540.

Quinn, E. A., Largado, F. E., Power, M., \& Kuzawa, C. W. (2012). Predictors of breast milk macronutrient composition in Filipino mothers. American Journal of Human Biology, 24(4), 533-540.

Roos, J. (2013). Relaxation and Induction of Lactation. http://idai.or.id/Publicarticles/Klinik/Asi/Relaktasi-Dan-InduksiLaktasi.html

Sitotaw, I. K., Hailesslasie, K., \& Adama, Y. (2017). Comparison of nutritional status and associated factors of lactating women between lowland and highland communities of District Raya, Alamata, Southern Tigiray, Ethiopia. BMC nutrition, 3(1), 61.

Soliman, S. M., Soliman, A. M., \& Bakr, M. S. (2014). Relationships between maternal nutritional status, quantity and composition of breast milk in Egypt. Afr J Ag Sci Technol, 2, 59-64

Vasudevan, C. (2019). POVERTY \& HEALTH: INCIDENCE, CAUSES, AND CONSEQUENCES OF MATERNAL ANAEMIA AMONG WOMEN POOR GROUPS IN INDIA-A LITERATURE SURVEY. International Journal of Research-GRANTHAALAYAH, 7(10), 75-93.

Verd, S., Ginovart, G., Calvo, J., Ponce-Taylor, J., \& Gaya, A. (2018). Variation in the protein composition of human milk during extended lactation: a narrative review. Nutrients, 10(8), 1124. 
Vinoy, S., Rosetta, L., \& Mascie-Taylor, C. G. N. (2000). Repeated measurements of energy intake, energy expenditure and energy balance in lactating Bangladeshi mothers. European journal of clinical nutrition, 54(7), 579.

WBTi. (2020). World Breastfeeding Trends Initiative. https://www.worldbreastfeedingtrends.org/

Yang, S., Martin, R. M., Oken, E., Hameza, M., Doniger, G., Amit, S., \& Bogdanovich, N. (2018). Breastfeeding during infancy and neurocognitive function in adolescence: 16-year follow-up of the PROBIT cluster-randomized trial. PLoS medicine, 15(4), e1002554. 